\title{
THE RHETORIC OF ANTIQUITY: POLITICO-RELIGIOUS PROPAGANDA IN THE NESTORIAN STELE OF CHANG'AN
}

\author{
安長
}

\author{
Max Deeg, Cardiff University (DeegM1@cardiff.ac.uk)
}

In a world in which the secular constitutions of democratic states regulate even the sphere of religious freedom we are accustomed to distinguishing clearly between the religious and profane spheres of society. The only exception we can think of is a state which is dominated by one religion, e.g. Islamic Iran. A look at the reality in Middle Europe, mainly in German-speaking countries, however, will reveal very quickly that this separation of political power and religion is a fata morgana at best: the two main churches, their priests and ministers and theological faculties at state universities are state-funded; the state raises church-taxes for the churches; in the schools, classes in Christian religion are compulsory, and the so-called substitutive classes in ethics and philosophy are not really well-established.

These remarks are not meant to be church-critical statements but only to highlight the close connection and interconnection of state and religion in the enlightened west as a historically normal case which can also be observed in the history of Chinese religions. The state controls but also protects the religion as long as the religion furthers the state, that is: the ruling dynasty or - in modern days - the party.

The typical do-ut-des ("I give you that you may give me") condition was that the state tolerated religion and may even have sponsored it to a certain extent, while religion stabilized the government and the rulers by concepts of bliss and legitimation and on the outside by ceremonies and rituals aiming at the prosperity of the emperor and his people.

After the first foreign religion had arrived in China in the shape of Buddhism competition rose between the autochthonous religions and systems of thinking, Ruism (Confucianism) 儒教 and Daoism, and the newcomer. This competition was about followers and believers, economic income and growth but not least about recognition through the instances of imperial power. In some cases as Liang Wudi 粱武帝 (r. 502 - 549), the Sui-emperors 隋 (581 - 618) and empress Wu Zetian 武則天 (r. $684-705)$ in the time of the Tang 唐 dynasty $(618$ - 907) the personal religious preferences of rulers are quite clear, but often and quite understandably the historical sources of each religion claim a ruler to be its special supporter.

What could a religion, especially a foreign, non-Chinese religion claim to bring as a benefit to the state and to the ruling dynasty? If one looks at the rhetoric of 
Chinese religious documents two things become clear very soon: first of all it had to adapt itself to the mainstream terminology of official documents and had to use this discourse in claiming to have gained the support of the emperor who was ruling at a particular historical moment when the religious document was composed, or at least to have had the support of emperors which official historiography found worthy of being "good rulers".

The peak of religious and cultural pluralism in imperial China was definitely reached under the rule of the Tang-dynasty, very often said to have been the "Golden Age" of the Chinese empire. Buddhism achieved its highest degree of development under this dynasty with the formation of Chinese Buddhist schools (Chan 禪, Jingtu 淨土, Huayan 華嚴, Lüzong 律宗) which were more or less independent of developments in India proper. During this period also Chinese Buddhist monks, such as Xuanzang 玄牀 (travelled 627 - 644), Yijing 義淨 (travelled 671 - 695), Songyun 宋雲 (travelled in the early $6^{\text {th }}$ century) and others travelled extensively to Central Asia, ${ }^{1}$ South-East Asia and India, while Indian monks like Vajrabodhi / Jin'gangzhi 金剛智 (671 - 741), Amoghavajra / Bukong(jin'gang) 不空(金剛) (705 - 774) and Śubhākarasiṃha / Shanwuwei 善無畏 (arrived in China 716) travelled as disseminators of esoteric Buddhism in order to bring the new religious "trends" in India to the Middle Kingdom (Zhongguo 中國). ${ }^{2}$

It was, however, also under the Tang that new foreign religions arrived in the empire, and it was mainly from Persia (Iran) that more and more adherents of these religions came to China as a result of the Islamic conquest of the PersianSassanian empire.

In the year 694 the empress Wu Zetian received a Persian Manichaean "episcopus" (bishop), whose religion was called Mingjiao 明教, the "Brilliant Teaching", in Chinese. ${ }^{3}$ But it has been the conversion to Manichaeism through the Uighur Qagan during his imprisonment in Luoyang 洛陽 in the year 762 that made Manichaeism to the state religion of the Uighurs for a certain period. However, this led to the prosecution of Manichaeism by the Tang in the year 840 when the Uighur empire collapsed.

It is probable that Zoroastrianism, the "state-religion" of the Sassanids, arrived in China already in an earlier period, through Persian merchants, and finally, under the Tang, through refugees from the increasingly troubled Sassanian empire. Only a few hints exist about the "fire-religion" which seems to have been restricted to the Iranian diaspora in China. The Chinese term for Zoroastrianism was xian 祅, which means according to the American Sinologist Edwin Pulleyblank "god", "god heaven" (: Skt. $\operatorname{deva}$ ) and is alternatively found in the more detailed expression huo-

\footnotetext{
${ }^{1}$ On the pilgrims see Max Deeg, Das Gaoseng-Faxian-Zhuan als religionsgeschichtliche Quelle. Der älteste Bericht eines chinesischen buddhistischen Pilgermönchs über seine Reise nach Indien mit Übersetzung des Textes, Wiesbaden 2005 (Studies in Oriental Religions 52), especially $51 \mathrm{ff}$.

${ }^{2}$ See Weinstein, Stanley, Buddhism under the T'ang, Cambridge 1987; Kamata Shigeo 鎌田茂 雄, Chūgoku-bukkyō-shi 中國仏教史, Tokyo 1984.

${ }^{3}$ See Lieu, Samuel N. C., Manichaeism in Central Asia and China, Leiden, Boston, Köln 1998 (Nag Hammadi and Manichaean Studies XLV).

Max Deeg, 'The Rhetoric of Antiquity. Politico-Religious Propaganda in the Nestorian Stele of Chang'an 安長, in: Journal for Late Antique Religion and Culture 1 (2007) 17-30; ISSN: 1754-517X; Website: http:/www.cardiff.ac.uk/clarc/jlarc
} 
xian 火祅, “fire god". ${ }^{4}$ Zoroastrianism - as all foreign religions in Tang-China has been affected by the persecution of Buddhism in the year 845 but it has, despite or because of its quantitatively low profile, never completely disappeard in the integrated Persian upper-level diaspora. A Pahlavi-Chinese bilingual graveinscription dated to the year 874 is very impressive proof of this. ${ }^{5}$

The religion from Iran which is first historically documented in Tang-China is that of the Eastern or Assyrian Church, usually called Nestorianism and Jingjiao 景教 / Keikyō in Chinese or Japanese. ${ }^{6}$ It is from this religion that one of the most celebrated religious documents of the Tang period originated: the Nestorian stone tablet or the Nestorian stele of Chang'an, the Daqin-jingjiao-liuxing-zhongguo-bei 景教流行中國碑, “Stele of the Diffusion of the Brilliant Teaching in the Middle Kingdom." The stele was (re)discovered in the year 1623 (or 1625). It was erected in the year 781 and covers the history of Nestorianism in China from its introduction in the year 635 to the year of its erection. In the west it has been the subject of continuous discussion by missionaries who considered it to be an early sign of the Christian presence in China and a legitimacy for mission activities but critics like Voltaire doubted its authenticity, and there were those who claimed it to be a fraud of the Jesuits in China. ${ }^{8}$

The stele is clearly datable by its Chinese and Syriac colophones to Sunday, February 4 of the year 781 (western calendar) - second year of the era Jianzhong 建中, first month (Taicu-yue 太蔟月), seventh day Da-yaosenwen(-ri) 大耀森文 (日) (according to Pelliot a transcription of Pahlavi ' $e v$-šambat $t^{9}$ ); in the year 1092 of the Greek calendar (12 years after the death of Alexander the Great and the conquest of the Seleucids in B.C. 311). The "author" of the stele is a priest called Jingjing 景淨 (Jingjing-shu 景淨述) whose name is given as Adam in the Syriac colophone; this colophone also specifies that it was the father of Jingjing / Adam, a chorepiscopus of Kumdān (Chang'an 長安) called Yisi 伊斯 / Yazadbōzīd (“the one saved by God") who had the stele erected.

\footnotetext{
${ }^{4}$ Pulleyblank, Edwin G., "Chinese-Iranian Relations I. In Pre-Islamic Times," in: Ehsan Yarshater (ed.), Encyclopaedia Iranica, Volume V: Carpets - Coffee, Costa Mesa 1992.

${ }^{5}$ Humbach, Helmut (with collaboration of Wāng Shìníng), "Die Pahlavi-Chinesische Bilingue von Xi'an," in: Acta Iranica 28, Leiden 1988 / Hommages et Opera Minora, vol.XII, A Green Leaf. Papers in Honour of Professor Jes P. Asmussen, 73-82.

${ }^{6}$ On Jingjiao during the Tang and the Yuan (Mongol) periods see the recently published collection of articles: Roman Malek, Peter Hofrichter (eds.), Jingjiao. The Church of the East in China and Central Asia, Sankt Augustin 2006 (Collectanea Serica). A collection of critical articles on Jingjiao in the Tang era in Chinese see Lin Wushu 林悟殊, Tangdai-jingjiao-zai-yanjiu 唐代景 教再研究, Beijing 2003.

${ }^{7}$ Pelliot, Paul / Forte, Antonino (ed.), L'inscription nestorienne de Si-Ngan-Fou, Edited with Supplements by Antonino Forte, Rom / Paris 1996 (Italian School of East Asian Studies Epigraphical Series 2 / Collège de France, œuvres posthumes de Paul Pelliot, subsequently quoted as Pelliot). I would also like to refer to my forthcoming German translation and commentary of the stele text.

${ }^{8}$ For an overview of the history of the discovery of the stele see the introduction in Pelliot.

${ }^{9}$ See Pelliot, 308f., note 281.

Max Deeg, 'The Rhetoric of Antiquity. Politico-Religious Propaganda in the Nestorian Stele of Chang'an 安長,' in: Journal for Late Antique Religion and Culture 1 (2007) 17-30; ISSN: 1754-517X; Website: http://www.cardiff.ac.uk/clarc/jlarc
} 
Beside this monumental document of the existence of a Christian Church in the Tang-empire other Nestorian texts have been found in the first decades of the $20^{\text {th }}$ century mainly through the manuscript collecting activities of Japanese scholars in mainland Chinese. These documents have unfortunately not been made freely available to the scholarly public since their discovery, and some of them may have been lost during the turmoil of World-War II. ${ }^{10}$ In the west they are usually called Dunhuang-documents although the place of their original discovery is far from being clear. These documents are: ${ }^{11}$

1. Xuting-mishi-suo-jing (yijuan) 序聽迷詩所經, “Sütra of Hearing the Preaching of the Messias"

(The following three texts were called Yishen-lun一神論, “Treatise about the One God" by Haneda Tōru:)

2. Yu di'er 喻第二, “Similis, Number 2"

3. Yitian-lun diyi 一天論第一, "Treatise of the One God (Number 1) "

4. Shizun-bushi-lun disan 世尊布施論第三, “Treatise on the alms-giving of the World-Honored-One (Number 3)"

5. Jingjiao-san-weimeng-du-zan 景教三威蒙度讚, “Eulogy of the Pāramitā of the Three Majesties of the Radiant Teaching”

6. Zun-jing 酎經, "Sütra of Veneration”"

7. Zhixuan-anle-jing 至玄安樂經, “Sūtra on the Supreme and Mysterious Joy"

8. Daqin-jingjiao-xuanyuan-(zhi)ben-jing 大秦景教宣元至本經, “Sūtra on the Origin of Origins of the Radiant Teaching from Daqin"

9. Daqin-jingjiao-dasheng-tongzhen-guifa-zan 大秦景教大聖通真歸法讚, "Eulogy of the Refuge to Law of the the Penetrating Truth of the Great Saint of Daqin"

What I want to show here with a few examples from the text of the stele is how a document like the Nestorian stele conveys much more meaning than the surface of the language would suggest at first glance.

As any document of official or semi-official status the stele-text is full of rhetoric, but before we get to the analysis of this rhetoric I would like to discuss some basic issues of semiotic and communication theory. The most primitive model of

\footnotetext{
${ }^{10}$ See Enoki Kazuo, "The Nestorian Christianism in China in Mediaeval Time according to Recent Historical and Archaeological Researches," in: Atti del Convegno Internazionale sul tema: L'Oriente cristiano nella storia della civilità ..., Roma 1964 (Problemi attuali di scienza e di cultura 62), $45-77$.

${ }^{11}$ Still mainly used but full of misinterpretations: Saeki, Peter Y., The Nestorian Documents and Relics in China, ${ }^{2}$ Tokyo 1951. The study of the texts has unfortunately been made under overtly Christian presuppositions, for which see Deeg, Max, „Verfremdungseffekt beim Übersetzen und „Wieder“-übersetzen der chinesischen Nestorianica,“ in: Berner, Ulrich; Bochinger, Christoph; Hock, Klaus (Hrsg.), Das Christentum aus der Sicht der Anderen, Frankfurt am Main 2004 (Beiheft der Zeitschrift für Mission 3), 75-104. For a balanced presentation see Pénélope Riboud, "Tang," in: Standaert, Nicolas (Hrsg.), Handbook of Christianity in China, Volume One: 635 - 1800, Leiden / Boston / Köln 2001 (HdO IV.15.1), 1-43. 
communication is that of a sender sending a signal and a receiver receiving the signal. If both sender and receiver use the same communicative code, it is assumed that the communication is successful, that is: there is understanding. This may be expressed in a very simple chart:

sender $\rightarrow$ medium $/$ code $\rightarrow$ receiver

Now, if a sender sends a message $\mathrm{A}$ and if it is presumed that sender and receiver are in control of the same code, the receiver should receive / comprehend the same message A. The fact, however, that the meaning of a linguistic element, let us call it a word, is not fixed in the sense that despite its common semantic centre different people will understand different undertones. Meaning, therefore, is rather a bundle of connotations around a semantic centre. According to this very simple semantic conception a communication could be systematically depicted as:

sender: message $A_{1} \quad \rightarrow \quad$ receiver: message $A_{2}$

It is quite clear that as historians we would like to know first of all what the intended message $\left(\mathrm{A}_{1}\right)$ was and then - maybe and rather rarely - proceed to the question how the people of the time understood this message $\left(\mathrm{A}_{2}\right)$. Another important question, which is usually excluded from the historian's reflective standpoint, is his own presupposition in understanding the message $A_{1}$, which may be different from it and from $\mathrm{A}_{2}: \mathrm{A}_{3}$. The ideal way of historical hermeneutics is that $A_{3}$ would be as authentic and identical as possible with $A_{1}$ and $A_{2}$. This would then mean that the historian could understand the same connotational range as a presupposed sender and receiver of the historical context and that he or she would include the complete range of allusion and rhetoric.

One of the characteristics of rhetorical speech is that it reflects at least two semantic levels which might be called expressive and allusive. On the expressive level a text reflects what (almost) everyone knowing a language would understand as its meaning, that is, according to our explanation above, the semantic centre. On the allusive level - the connotational and contextual fringes of the meaning what is understood depends heavily on the cultural and educational background of the receiver.

In the Chinese context the authority of a text is very often built up by quoting from some classic sources and these sources receive their authority through their antiquity - they reach back to an idealized "in illo tempore". The most "canonical" of these texts, because they are considered the most ancient, are the four "classics" (sijing 四經) Shijing 詩經, Yijing 易經, Shujing 書經, the Ruist (Confucian) “classics” Lunyu 論語, Zhongyong 中庸, Daxue 大學 and Mengzi 孟子 and the two Daoist “classics”, the Daodejing 道德經 and the Zhuangzi 莊子.

Based on the models of communication and semiotics, which have been explained, it seems reasonable, if a certain expression or a certain phrase is quoted from a classical text, that it refers rather to its closer, expressive semantic. Very 
often, however, a quotation is not only meant to invoke this basic meaning of an expression or phrase but also the whole context of its original "setting". If this is the case, this allusive context may not only help us to understand the right meaning of the citation but also to reconstruct the underlying broader meaning as, for example, the historical context which is alluded to.

It is certainly not an exaggeration to say that almost every famous western Sinologist from the $19^{\text {th }}$ century onwards has translated or written about the Nestorian stele of Chang'an. Most of them - except the great French Sinologist Pelliot - have treated the text as a Christian document in the first instance and only secondly as a piece of fine Chinese epigraphical literature. The consequence was that they were very often obsessed with the idea of hunting down Biblical and Christian meaning in the Chinese texts instead of trying to understand them in their own cultural context which was definitely a Chinese readership with a high standard of literacy. My thesis is that a lot of the allusive meaning especially of the terminological quotations from and references to the classics was not discovered or not understood. I will give some examples for this thesis, but first let us look at the political context in which the stele was composed.

The Tang dynasty had already had quite a history of its own, with ups and downs, when the stele was erected in 781 under emperor Dezong 德宗 (r. 779 805). The first decades can be described as years of expansion and of the consolidation of power under the emperors Gaozu 高祖 and Gaozong 高宗. They were followed by the interregnum of the only empress China ever had, Wu Zhao 武眐 or $\mathrm{Wu}$ Zetian, who was heavily criticised by following generations of officials and historians. The two short-lived reigns of Wu Zetian's sons Zhongzong 中宗 (r. 705 - 710) and Ruizong 荃宗 (r. 710 - 712) marked the transfer of power back to the Tang and ended in the long reigning period of Xuanzong 玄宗 (r. 712 - 756).

Now the stele alludes to these events of the past in several places. I would like to concentrate here on references to the great revolt of An Lushan and the period of instability after it $(755-763)$. The author of our text clearly uses quotations single terms and complete or sometimes slightly changed phrases - not only to refer to these events but also to express his thoughts and judgement. These kinds of statement are expressed, of course, in favourable terms and as a captatio benevolentiae ("getting the favour") of the ruling emperor and it would have been quite awkward to directly criticize earlier emperors of the same dynasty, the Tang.

One way of avoiding direct criticism of the actions of earlier Tang rulers was silence; the author of the stele just avoids the name of the ruler(s) under whose reign the discreditable events took place.

We can see this in the case of the two short reigns of the emperors Zhongzong 中宗 and Ruizong 荟宗. They were, after all, still legitimate rulers of the Tang dynasty, while their mother, Wu Zetian, considered as a female usurper, had caused the interregnum of the Zhou dynasty and could rightly be criticized by mentioning the name of the ancient Zhou capital (empress Wu had transferred the capital from Chang' an to Luoyang, the eastern capital): 
"In the years of the (era) Shengli the sons of the Siakya strutted around (and) rose their prattle in the eastern (capital) of the Zhou. At the end of the (era) Xiantian inferior scholars roared with laughter (and) were slandering in Xihao."12

Also in this short text passage, covering a period of about fifteen years - between the era Shengli 聖曆 $(698$ - 700) and the end of the era Xiantian 先天 (at the end of the year $713^{13}$ ) - phrases from classical literature are used to express the judgement of the author:

The two capitals mentioned are Luoyang - Dongzhou 東周 as the capital of empress $\mathrm{Wu}$ - and Chang'an - Xihao 西鎬 - as the restored capital of Wu's sons, Zhongzong and Ruizong. Xihao usually refers to the capital of the western Zhoudynasty (1045 - 771 B.C.). The two names of the capital create a clear connection with the old Zhou-dynasty and probably have a symbolic meaning: the period of the reign of king Ping 平 $(770-720$ B.C. $)$ of Zhou who founded a new capital in the east of his empire on the banks of the Luo river (Luoyang), is traditionally seen as the period in which with the eastern Zhou $(770-221$ B.C.) the decline of the Zhou-dynasty began, as the Grand Historian Sima Qian 司馬遷 states:

"After king Ping had ascended the throne he moved (his court) to the east, to Luo-yi, to avoid conquest by the Rong(-barbarians). In the time of king Ping the house of the Zhou declined, ..."

Luoyang in the context of the empress' Zhou-dynasty thus indicates the place in which the period of decline - Wu's reign - began. This may also be alluded to by the notion of the era Shengli, which according to other Chinese sources, had not been a period of extraordinary Buddhist influence and of persecution of other religions as expressed by the stele but was marked as the time in which the power of empress $\mathrm{Wu}$ was indeed fading away: The empress was at that time already weakened through illness ${ }^{15}$ and her dependence on her new favourites, the brothers Zhang 張 Yizhi 易之 and Changzong 昌宗; at the end of the era Shengli she had already given up all her Buddhist titles such as Bodhisattva / pusa 菩薩 or Sacred Wheel-Turning King (cakravartin / sheng-zhuanlun-wang 聖轉論王). The period of her intensive support for Buddhism, marked by her favourite (and lover?), the (pseudo-)monk Xue Huaiyi 薛懷義 ${ }^{16}$, was already over. The only Buddhist activities in this time were sūtra translations - for example the Avatamsaka-sūtra / Huayan-jing 華嚴經 under the guidance of the Khotanese monk Śikșānanda and the imperially patronized translations of the famous pilgrim Yijing 義淨 who had returned to China in 695 - and the activities of well-known Chan-masters to the

127 聖曆年, 釋子用壯, 騰口於東周 ; 先天末, 下士大笑, 訕謗於西鎬。

${ }^{13}$ Pelliot, 254, note 144, calculates from September 12, 712, until December 21, 713 (the official beginning of the era Kaiyuan 開元).

${ }^{14}$ (Shiji 史記 4): 平王立, 東遷于絡邑辟戎完。本王之時, 周室衰微。

${ }^{15}$ See R.W.L. Guisso, Wu Tse-T'ien and the Politics of Legitimation in T'ang China, Bellingham 1978, 147. In this period also occurs the healing of the empress' disease by a Buddhist monk, an event which is, however, only mentioned in the Zizhitongjian 資治通鑑 of Sima Guang 司馬光 (c. 1084) and in none of the Tang-historiographies: see Guisso (1978), 287, note 154.

${ }^{16}$ Huaiyi had been murdered at the beginning of the year 695 .

Max Deeg, 'The Rhetoric of Antiquity. Politico-Religious Propaganda in the Nestorian Stele of Chang'an 安長,' in: Journal for Late Antique Religion and Culture 1 (2007) 17-30; ISSN: 1754-517X; Website: http://www.cardiff.ac.uk/clarc/jlarc 
court of Luoyang 洛陽. ${ }^{17}$ The reference to the movement of the capitals under the old Zhou dynasty then adds another nuance: bringing the capital back to Chang'an is the start of the restoration of the Tang, though the first years of its formal reestablishment were still distinguished by some religious or ideological conflicts, which the stele describes as the "roaring of laughter of inferior scholars", xiashi da-xiao 下士大笑 and their slandering (shanbang 訕謗) (of other religions).

The first expression, xiashi da-xiao 下士大笑, is a clear quotation from Daodejing 道德經 41:

"If the superior hears of the Dao he is eager to practice it. If the mediocre hear of the Dao it partly perseveres and partly gets lost. If the inferior hears of the Dao he roars with laughter - if he did not laugh then it would not be sufficient to be the Dao." 18

There has been an uncertainty about who these "inferior scholars", xiashi 下 士, were. Saeki (p.59) translates "some inferior (Taoist) scholars". ${ }^{19}$ Paul Pelliot, p.254, note 145, rejects Saeki's translation and takes xiashi as Confucian scholars without giving any concrete reasons for his interpretation.

I think that in this very case Saeki has made the right interpretation for the following reasons: Formal: there is a clear and absolute parallelism between the two parts of the sequence: (a.) 聖曆年, (b.) 釋子用壯, (c.) 騰口於東周 : (aa.) 先天 末，(bb.) 下士大笑， (cc.) 訕謗於西鎬。 It is clear from other passages of the stele that a formal parallelism - mentioning the names of the eras and the parallel predicates yongzhuang 用壯 - daxiao 大笑/ tengkou 騰口 - shanbang 訕謗 - is always connected with correspondences in terms of content. The terminological connection to Daoism is clear; even the term shanbang 訕謗 has its locus classicus in a Daoist work, the Guanyinzi 關尹子 (Jiuyue 九第(+收)): “The Dao should not be taken too easily, the virtue (de) should not be mocked." 20 Using a Daoist term to slander Daoists here is a strong rhetorical and polemic instrument.

There is one problem involved in this interpretation: the era Xiantian is the beginning of the rule of emperor Xuanzong 玄宗 (reg. 712 - 756) who curtailed the influence both of Buddhism and of Daoism.

The period in which the pro-Buddhist policy of $\mathrm{Wu}$ Zetian and her first successor Zhongzong clearly swung in favour of the Daoists was the reign period of

\footnotetext{
${ }^{17}$ E.g. Zhixian 智先(+言), disciple of the fifth Chan-patriarch Hongren 弘忍 in the year 697: cp. in general Weinstein (1987), 44ff.

18 上士聞道, 勤而行之。中士聞道, 若存若亡。下士聞道, 大笑之。不笑不足以爲道。

${ }^{19}$ Followed, with some hesitation, by Moule, A. C., Christians in China Before the Year 1550, London 1930, 40f., note 27.

20 不可以輕忽道己, 不可以訕謗德已。 The Guanyinzi, also known under the name of Wenshi-zhenjing 文始真經, is a Daoist text known from the period of the late Han: Noguchi Tetsurō, Sakade Yoshinobu, Fukui, Fumimasa, Yamada Toshiaki, Dōkyō-jiten, Tōkyō 1994 野口 鐵郎, 坂出祥伸, 福井文雅, 山田利明, 道教事典, 東京, 524b.f., s.v. Bunshishinkyō. See also Bo Juyis Yuyuan-jiushu 與元九書, where it reads: 不相與者, 號爲沽名, 號爲詆訐, 號爲 訕謗。 ("Those who do not get along with each other are called ones 'fishing for fame', 'spreading gossip', 'mocking (others)'.’”)

Max Deeg, "The Rhetoric of Antiquity. Politico-Religious Propaganda in the Nestorian Stele of Chang'an 安長,' in: Journal for Late Antique Religion and Culture 1 (2007) 17-30; 
Zhongzong's brother Ruizong. ${ }^{21}$ Under the protection of Ruizong's powerful sister, princess Taiping (Taiping gongzhu 太本公主) ${ }^{22}$ Daoists like Zhang Wanfu 張萬 福 and Shi Chongxuan 史崇玄 came into influential positions similar to those of the great Buddhist figures under empress $\mathrm{Wu}$. Two imperial princesses and daughters of Ruizong were ordained as Daoist nuns and given honorary religious titles, Jinxian 金仙 (“Golden Immortal”) and Yuzhen 玉真 (“Jade-truth"). The political influence of princess Taiping and the already mentioned Daoist hierarchs lasted until the summer of the year 713 - indeed into the second half of the era Xiantian while we read of no direct Confucian action against other religions in the first years of Xuanzong's rule.

All these points show that the use of the Daode-jing quotation was meant as a criticism against the Daoist activities in the aftermath of the exercise of power by princess Taiping while Xuanzong was already consolidating his power. In both cases the Buddhists and the Daoists are described at the time when their decline was already predictable though they still exerted some power in politics.

After having criticized the internal Chinese religious adversaries, the Buddhists and the Daoists, the stele text continues with a eulogy of two Nestorian monks who, in the Nestorian tradition at least, are seen as the ones helping the Tang dynasty regain power:

"There were, (however, men) like the head of the monastic (order) Luohan 羅 含 and the dade 大德 (bhadanta) Jilie 及烈, being from noble origin and from the Region of Metal, eminent monk (and) detached from all things; together they reinstated the mysterious bond and reknotted the disintegrated meshes." 23

The meaning of these sentences can only be understood if the context of the quotation is taken into account. There is, first of all, the initiating expression you ruo 有若, “there were ... like ...”. It is, as the famous French Sinologist Paul Pelliot has already noticed, a reference to the Shujing. I would, nevertheless, suggest a stronger interpretation than Pelliot in drawing a parallel between the relevant Shujing-passages and the ideological intention of the author of the stele: in Shujing 5.16.1 (Legge, 474) the Duke of Zhou, Zhou-gong 周公, who was the real founder of the Zhou-dynasty, tries to persuade the prince of Shao 召, (Jun)Shi (君)䀽, to give up his court-office and one of his arguments in which our phrase occurs is that capable rulers always have capable advisers or ministers taking care of the prosperity and the stability of the dynasty and the empire:

5.16.7 (Legge, 477ff.) "(7.) The Duke said: 'O prince Shi! When the perfect Tang received the mandate (of Heaven) there was someone like Yi Yin, how caused (Tang) to act according (to the orders) of the Superior Heaven. Under the great

${ }^{21}$ See T. H. Barrett, Taoism under the T'ang. Religion \& Empire during the Golden Age of Chinese History, London 1996, 48ff.

${ }^{22}$ See Taiping's role after the restoration of the Tang and her attempt to lead a revolt against her newly enthroned nephew Xuanzong: Twitchett, Denis; Fairbank, John K., The Cambridge History of China, Volume 3: Sui and T'ang China, 589-906, Part 1, Cambridge, London 1979, $323-328$ and $343-345$.

23 有若僧首羅含，大德及烈；並金方貴緒，物外高僧。共振玄綱，俱維絕紐。 
Jia there was someone like Bao Heng, under the great Wu there was someone like $\mathrm{Zi}$ Zhi (and) minister Hu who caused (Jia and Wu) to act according (to the orders) of the Superior Heaven, and Wu Xian regulated the royal household. Under Zi Zi there was someone like Wu Xian; under Wu Ding there was someone like Gan Pan. (8.) They accordingly followed the example of each other, protected and regulated the continuity of the Yin(-dynasty) - that is why the (sacrificial) rituals of the Yin reached Heaven (and Yin) lasted for many years. ,,24

In 16.11 - 14 (and following) (Legge, 480f.) the duke justifies the present Zhourule and its legitimacy by means of the mandate of Heaven (tianming 天命) using the same phrase, you ruo 有若:

"(11.) The duke said: 'O prince Shi! In the past, when the Superior Ruler (i.e.: Heaven) destroyed (Yin) he cultivated the virtue of the peaceful king (Wen) and (transferred) his Great Mandate to the person (of king Wen).' (12.) Then (the duke) continued to say: 'The fact that king Wen was successful in cultivating and pacifying the empire and got it under our control is (because) there was someone like the count of Guo, someone like Hong Hao, someone like San Yisheng, someone like Dian of Tai, someone like Kuo of the Southern Palace. (13.) If (these) had not (frequently) been associated (with Wen) and had taught him, only a little virtue would have come down from king Wen to the people. (14.) They had made (Wen) recognize the majesty of Heaven only by the help of their solid virtue, (they) gradually enlightened (king) Wen, made him realize his failings and listen to the Superior Ruler (Heaven), in order to receive after a certain period of time the mandate (of Heaven) of the Yin. ", 25

It seems to be clear what is intended by the use of the Shujing phrase in the introduction of the two eminent Nestorian monks: rulers who had wrong (religious) advisors were doomed to decline. In antiquity this had happened to the last ruler of the Yin-dynasty, during the Tang to empress $\mathrm{Wu}$ with her Buddhist fellows, and to Ruizong who had depended on the Daoists. The new Tang-ruler Xuanzong is not mentioned in the text of the stele but it is clear that he, through the power of his own virtue (de 德) and with the help of true advisors, (re)gained the mandate of Heaven and reunified the empire like the legitimate rulers of the Yin-dynasty, Zhou Wu-gong 周武公 und Zhou Wen-wang 文王, assisted by their loyal minister and retainers.

But there is another quotation-element in the passage under discussion which does not refer to a real classical text. Paul Pelliot has emphasized that the author of the stele in several places refers to the so-called Dhüta-stele, the Toutuo-si-

24 公曰：君顺, 我聞在昔, 成湯既受命, 時則有若伊尹格于皇天, 在太甲, 時則有若保 衡, 在太戊, 時則有若伊陟臣扈格于皇天, 巫咸入王家, 在祖乙(, )時則有若巫賢, 在武 丁，時則有若甘盤。(8.) 率惟茲有陳，保义有殷，故殷禮陟配天，多歷年所。

25 公曰：君県，在昔上帝割，申勸寧王之德，其集大命于厥躬。(12.) 惟文王, 侣克修 和我有夏, 亦惟有若虢叔, 有若閏夭, 有若散宜生, 有若泰顛, 有若南宮括。(13.) 又曰： 無能往來, 茲迪彝教, 文王荿德降于國人。(14.) 亦惟純佑秉德, 迪知天威, 乃惟時昭文 王，迪見冒，聞于上帝，惟時受有殷命哉。 
beiwen 頭阤碑文 (Wenxuan 文選 $59^{26}$ ). The sentence gong zhen xuangang, $j u$ wei jueniu 共振玄綱, 俱維絕紐 is an almost identical quotation from the Dhütainscription:

“(Thereupon) both Aśvaghosa (Maming 馬鳴), the dark assistant, (and) Nāgārjuna (Longshu 龍樹), the investigator of the void, reinstated the mysterious bond and reknotted the disintegrated meshes." 27

The parallelism between the two stele-texts is more than a purely formal one and has to be seen in the context of the Dhüta-text where we find a passage before the one quoted describing the decline of the dharma after the nirvanna of the Buddha:

"The True Dharma had already perished, the Counterfeit of the Dharma was in continuous decline. Those (who) chopped the (correct meaning of the dharma), who taught wrong teachings, ${ }^{28}$ tried incorrect methods in order to achieve 'the One. ${ }^{29}$ Those who followed the false (doctrine) and those who discussed lies were familiar with hair-splitting debates." 30

Brought into the context of the Nestorian stele the almost complete parallelism is striking. The only small difference ${ }^{31}$ is the character xuan 玄, "mysterious, concealed" in xuangang 玄綱 instead of tui 䅡, “to collapse, to break apart", in the Dh. I think that the intention of the author was to show that the teaching has not been interrupted completely through the activities of the (Buddhist and Daoist) heretics but that it has kept its continuity through the "mysterious bond" (xuangang). Historically we may deduce two points from this parallelism: 1. the activities of the monks Luohan 羅含 and Jilie 及烈 were not simultaneous with the actions of the Buddhists and Daoists, and 2. Luohan and Jilie may not have acted at the same time - like Aśvaghosa and Nāgārjuna. This would support the relative chronology given by Pelliot, 257f., note 155, according to which Luohan arrived in China before 714 while Jilie came to China after 732 .

Although the author of the stele made his negative judgement of the reign of $\mathrm{Wu}$ Zetian and her followers very clear, however it would not have been such a good idea on the part of the Nestorians to criticize directly the predecessors of the emperor ruling at the time of the stele, especially Xuanzong, the emperor having ruled for over more than four decades but also having been - at least partly responsible for the greatest turmoil and revolt under the dynasty and those of the preceding centuries, the one of An Lushan 安祿山.

The whole purpose of the stele is to demonstrate that there is a connection between the rightful actions of the Tang rulers and the blissful presence of the Ne-

\footnotetext{
${ }^{26}$ The text had been known to an educated Tang-readership: the Wenxuan had been part of the official literary canon of examination in the Sui- and Tang-dynasty.

${ }^{27}$ P.1439, $1.7 \mathrm{ff}$. 馬鳴幽讚, 龍樹虛求, 並振頽綱, 俱維絕紐。

${ }^{28}$ Compare Lunyu 2.16 (Legge, 150).

${ }^{29}$ Compare DJ 39: $y i$ - here means the Dao.

${ }^{30}$ P. $1439,1.7 \mathrm{ff}$. 正法既沒, 象法陵夷。穿鳌異端者, 以違方爲得一; 順非辯俘者, 比徵 言於目論。

${ }^{31}$ There is another one: instead of bing 並 in Dh. N. has gong 共 and this seems to be causa variationis as bing is already occurring behind the name of the two monks.
} 
storian Church in China, both guaranteeing the order of the oikumene (tianxia 天 下) and the stability of its underlying transcendent principle, the Dao.

In this context it is striking that the concrete historical situation is usually refered to by quotations from the Shijing and the Shujing while the more religioideological allusions in the stele are accomplished by citations from the classical Daoist literature, especially the Daode-jing.

The Nestorians had, of course, given their due tribute to the ruling emperor, Daizong who is depicted as having stabilized Tang-rulership again.

A nice example of how the author combines Nestorian self-propaganda with eulogy of the emperor Suzong 肅宗 (r. 756 - 762) and severe criticism of the shortcomings of his predecessor Xuanzong during the revolt of An Lushan is found in the poetic passage on Suzong:

"Suzong came in order to re-establish (rulership),

(and) the 'Dignity of Heaven' led the procession.

The sacred sun displayed his brightness,

the blissful wind swayed away (the darkness) of the night.

Bliss came back to the imperial house,

the disastrous haze dissolved forever.

The surge was stopped, the stirred dust was calmed down.

(and) our region of the Xia was (re)established." 32

There are several expressions and phrases quoted from classical literature. I indicate only the most important ones for the understanding of this passage: first in the second line tianwei yin-jia 天威引駕. As Pelliot has already shown tianwei 天 威 is directly referring to the emperor Suzong ${ }^{33}$ and the point of reference in classical literatur is Shujing 5.1.1.6 (Legge 3, 285):

"The Superior Ruler was outraged [by the evil actions of the Yin-rulers] (and) ordered my late father Wen to respectfully show the dignity of Heaven (tianwei); but he (was unable) to finish the great meritorious (work)., 34

In this famous chapter called Great Vow, Taishi 泰誓, the Zhou-king $\mathrm{Wu}$ 武 speaks about his father Wen 文 who had killed the last and corrupt Yin-ruler and thus had fulfilled and received the mandate of Heaven (tianming 天命) as the ultimate legitimation of the sovereignty of the Zhou. The epithet shenwei 天威 for Suzong is a reminiscence to the Shujing passage and is probably meant as a legitimation of the taking over of power through Suzong which meant a dethronement of his father Xuanzong who had fled from the troops of An Lushan to the Sichuan.

\footnotetext{
32 肅宗來復, 天威引駕。聖日舒晶, 祥風掃夜。祚歸皇室, 祅氛永謝。止沸定塵, 造我 區夏。

${ }^{33}$ See also in a poem of the famous Tang poet $D u F u$ 杜甫 $(712$ - 770) (Chengwen-Hebeizhujiedu-ruchao-huanxi-kouhao-jueju 承聞河北諸節度入朝歡喜口號絕句 12): 十二年來多戰 場, 天威已息陣堂堂。( “Since twelve years constantly on the battlefield, His Heavenly Majesty has far and away calmed down the battle formations. ”)

34 皇天震怒, 命我文考, 肅將天威, 大勳未集。

Max Deeg, 'The Rhetoric of Antiquity. Politico-Religious Propaganda in the Nestorian Stele of Chang'an 安長,' in: Journal for Late Antique Religion and Culture 1 (2007) 17-30; ISSN: 1754-517X; Website: http://www.cardiff.ac.uk/clarc/jlarc
} 
Pelliot interprets the “enigmatic” yin-jia 引駕, literally: “(he) pulls the cart”, as an allusion to the reception which Suzong prepares for his father Xuanzong when he comes back to Chang'an, leading ( yin 引) the ex-emperor's entourage (jia 駕) back to the capital. I think, however, that there is a another layer of reference beyond this concrete one, namely is the connection between the successful actions of the emperor in crushing the revolt of An Lushan and the assumed positive influence of the Nestorian religion. The Zhou-rulers Wen 文 and $\mathrm{Wu}$ 武 finally are only able to defeat the tyranny of the Yin 殷 - corresponding to the attempt of An Lushan to usurp power - because the last Yin ruler acts against the will of the Heavenly Ruler (tian 天, shangdi 上帝) who subsequently bestows victory and rulership on Wen and $\mathrm{Wu} .{ }^{35}$ The rulers are the rightful representatives of Heaven and that is why they partake in the dignity of Heaven $\left(\right.$ tianwe $\left.^{36}\right)$. In the scheme of interpretation of the Nestorians the Heavenly Ruler or the Heaven could not be anyone else than their own god and it is through his power that Suzong is able to reinstitute the true rule of the Tang.

The phrase zhi fei, ding chen 止沸定塵 is a well-attested metaphor for war and turmoil also for the Tang period but $f e i$ 沸 as an image for chaos and decline is already found in Shijing 3.3.1.6 where king Wen of Zhou criticizes the decadence of the last Shang-ruler:

"King Wen said: 'Oh, you (ruler) of Yin-Shang! (Everything now) is like (the chirping) of the crickets, of cicadas; like the surging of hot broth - big and small are approaching decay.", 37

Another phrase, zao wo qu-Xia 造我區夏, is directly taken over from Shujing 5.9.4 and again king Wen of Zhou - as the model ruler of antiquity for Suzong - is the subject of the description:

"He [king Wen] did not take it upon himself to neglect the widows and the orphans. He employed those who were useful, paid reverence to the venerable ones, threatened those who were a threat and he thus was respected by the people. In

\footnotetext{
${ }^{35}$ Compare Shujing 5.1.1.4. 今商王受，弗敬上天，降災下民。(“Now the Shang-ruler does not pay respect to the Supreme Heaven, causes calamity on his people."); 9. 商罪實盈, 天命誅 之, 予弗順天, 罪厥惟鈞。("The offences of the Shang are complete, indeed; Heaven gives an order to destroy them. If I did not follow Heaven, (my) offences would be similar to his'."); 10. 予 小子夜祗懼, 受命文考, 類于上帝, 宜于冢土, 以爾有眾, 氐天之罰。(11.) 天矜于民, 民 之所欲, 天必從之, 爾晌颂予一人, 永清四海, 時哉弗可失。(“10. I, the inferior, have received the mandate (of Heaven) from (my) late (father) Wen. I have given the Supreme Ruler a special (sacrifice), have sacrificed to the Great Earth what she is entitled to receive. I have led many of you (who acted against Heaven) to the punishment of Heaven. 11. Heaven is compassionate: what is wished through the people Heaven will certainly grant. Help me as the one man who will forever cleanse (the region between) the Four Oceans. It is due time! (I) will not fail.")

${ }^{36}$ For tianwei as referring to heaven see Shujing 5.16.3: 我亦不敢寧于上帝命, 弗永遠念天 威, 越我民岡尤違, 惟人, ... (“I [the Duke of Zhou] do not dare to repose on the mandate of the Supreme Ruler; (I) will not always ponder the Dignity of Heaven")

37 文王曰：咨，咨。女殷商。如蜩如螗。如沸如美。小大近啔。

Max Deeg, "The Rhetoric of Antiquity. Politico-Religious Propaganda in the Nestorian Stele of Chang'an 安長,' in: Journal for Late Antique Religion and Culture 1 (2007) 17-30; ISSN: 1754-517X; Website: http://www.cardiff.ac.uk/clarc/jlarc
} 
the beginning he established the (empire of) Xia in our region, exerted influence beyond our one or two kingdoms and our western countries placed themselves under his protection. When the Supreme Ruler heard this, the (Supreme) ruler bestowed the Great Mandate on king Wen, had (him) subdue Yin, had Wen receive in full their Mandate and even their dominions whose peoples were regulated."38

What is meant here is that Suzong - like king Wen for the Zhou - establishes the mandate of Heaven for the Tang and reinstitutes ( $z a o$ 造) the unification of the empire: wo qu-Xia 我區夏. The context of the Shujing citation again implies the influence of Heaven (tian 天) of the Supreme ruler (shangdi 上帝) who, in a Nestorian interpretation, could be no other than the almighty God of the Christians. ${ }^{39}$

I hope that I have been able to demonstrate how a careful and contextualizing reading of Chinese official or semi-official texts like the Nestorian stele of Chang'an may reveal quite a lot more meaning - the intentions of the authors and what was understood by a respective readership - than what is lying on the surface. This is done in the cases under discussion by quoting directly, or indirectly referring to, texts and episodes in Chinese antiquity which were very well known to a welleducated audience. The purpose was very often to bring forth criticism against other religious groups or even political figures of the Tang-period or Nestorian self-propaganda which, had it been uttered in a plainer and more direct way, would have caused quite a deal of problems to a religious group which was definitely seen as being of foreign origin and which could be ignored in the powerplay of Tang politics, especially after the fall of the Sassanian empire.

38 不敢侮鯭寡, 庸庸, 祗祗, 威威, 顯民, 用肇造我區夏, 越我二二邦以修, 我西土惟 時怙冒，聞于上帝，帝休，天乃大命文王，殪戎殷，誕受厥命，越厥邦厥民惟時敘。

${ }^{39}$ A similar conception of the mandate of Heaven is found in Zhang Heng's 張衡 Dongjing-fu 東京賦, preserved in Wenxuan 文選: 且高既受命建家, 造我區夏矣。( “After the High (Ruler) had received the Mandate (of Heaven) he established the (dynastic) house and created our Empire (qu-Xia).”)

Max Deeg, "The Rhetoric of Antiquity. Politico-Religious Propaganda in the Nestorian Stele of Chang'an 安長, in: Journal for Late Antique Religion and Culture 1 (2007) 17-30; ISSN: 1754-517X; Website: http:/www.cardiff.ac.uk/clarc/jlarc 